\title{
If Worlds Were Stories
}

Martin Klebes

University of Oregon

The metaphysics of possible worlds proposed by the analytic philosopher David K. Lewis offers an account of fictional discourse according to which possible worlds described in fiction are just as real as the actual world. In an inspired reversal of the analysis of literary fictions by such philosophical means, the French poet Jacques Roubaud makes direct reference to Lewis' controversial ontological picture in two cycles of elegies composed between 1986 and 1990. Roubaud's poems take up the idea of possible worlds as real entities, and at the same time they challenge the notion that philosophy could offer an account of fiction in which the puzzling collision of the possible with the impossible that fundamentally characterizes the phenomenon of fictionality would be seamlessly unravelled. For Roubaud the lyrical genre of the elegy and its thematic concern with love and death stands as a prime indicator of the quandary that results from our inability to solve paradoxes of modality such as those raised by Lewis in strictly theoretical terms.

It is no well-kept secret that substantial points of contact between contemporary analytic philosophy on the one side, and the domain of literature and its study on the other, are primarily conspicuous by their absence. While one might argue that permanently ongoing differentiation necessarily condemns either side to considering the other incommunicado, for better or worse, the descendants of Carnap and the practitioners of what the German academy designates as the 'science of literature' (Literaturwissenschaft) certainly entertain no straightforward relationship to science and the development of its disciplines. Regardless of whether theoretical enterprises such as the causal theory of knowledge or a strictly empirical science of literature as Siegfried J. Schmidt once sought to establish it may accurately be modeled on pursuits in the natural sciences, occasionally we do witness the emergence of a framework which-even if not precisely "revolutionary" in the Kuhnian sense-suggests conceptual overlap between disciplines that otherwise tend to go their increasingly separate ways.

The pervasive talk of possible worlds in analytic philosophy and literary studies since the 1970s is one such case. While by no means deliberately conceived as an engine of interdisciplinarity, the adoption of the notion of possible worlds by modal logicians was followed by its subsequent dispersal not only to a number of other subfields in philosophy but also to linguistics and narratology. Scholars of a non-analytic bent quickly picked up on the fact that the notion of possible worlds did not constitute a 
radical conceptual break with the past but in fact had a far-flung intellectual ancestry in the writings not only of Leibniz but also of writers such as Fontenelle and the godfathers of German-language literary criticism, Bodmer and Breitinger. ${ }^{i}$

Moving from the most abstract level of the theoretical invocation of an array of possible worlds for any number of potential theoretical objectives to the concrete theoretical context particularly relevant to the following reflections, the issue most directly linking philosophical and literary interest in possible worlds talk is its applicability to an analysis of the phenomenon of fictionality. In one way or another, the kinds of analyses in question present fictional discourse as a linguistic domain that makes reference to possible worlds-worlds, that is, which are not identical to the actual world that surrounds us.

From the perspective of analytic philosophy of language, theories of fiction modeled on possible worlds are primarily designed to resolve the puzzles presented by fictional discourse for a consistent account of meaning across all domains of language. Possible worlds talk offers the tantalizing perspective of departing from the reductive fixation on empirical verification that had compelled the early logical positivists to equate all non-literal language with nonsense-fit to express (non-theoretical) attitudes but not to assert statements (Carnap 78-80)—while at the same time preventing metaphor from sowing the seeds of radical skepticism about actuality.

The motivation to be discerned on the other side of the coin, namely among scholars of literary narrative who adopt some version of the possible worlds framework, is to some degree convergent with this interest in preserving the integrity of reference. Thomas Pavel remarked well over 20 years ago that "the moratorium on referential issues" as an operative guideline in literary theory had become "obsolete" (Pavel 10), and even though he rejected the interpretation of fictional worlds as objects to be reduced outright to the abstract notion of possible worlds employed in modal logic (49), he nevertheless advocated the import of the "world" concept (back) into literary studies, in response to prior insistence among structuralists and poststructuralists that hors-texte there was no such world to be found. By the very nature of their object of analysis, literary theorists such as Pavel and Lubomír Doležel, however, take a considerably wider view of reference than most analytic philosophers, one 
according to which the primary task in evaluating a piece of fictional discourse is not in every instance to achieve consistency with a presumably shared sense of a common actual world. While he does not call the cognitive value of literary fictions into question, the purpose of many types of the latter, according to Pavel, "is less to increase the trade in conventional wisdom than to expand our perception of fictional possibilities" (Pavel 84). Fictionality, hence, is not considered a mere obstacle potentially impeding the unequivocal assessment of what there actually is; its practices of referring to worlds more generously than may seem warranted in certain philosophical circles, Pavel argues, "are perceived as marginal only in contrast to some culturally determined ossification into normality" (27), one that by no means constitutes an absolute standard.

Even if the narratological elaboration of making sufficiently secure reference to a plurality of fictional worlds does not adopt the modal-logical notion of possible worlds wholly as its own," it would seem initially plausible that the versions of possible worlds theory most frequently examined for its potential adaptation to literary contexts are those that consider possible worlds as objects that are made rather than found, as the result of calculated poiesis rather than the sheer luck (prompted, perhaps, by assiduous observation) of discovery. In the memorable formulation offered by Saul Kripke: “'Possible worlds' are stipulated, not discovered by powerful telescopes” (Kripke 44). At least as regards their ontological status, then, the possible worlds devised by analytic philosophers such as Kripke, Plantinga, Stalnaker, Rescher and others may seem amenable to the literary theorist focusing on fictionality in that these possible worlds are acknowledged to be strictly of our own making, rather than being part and parcel of any essential furniture of the universe. On one interpretation, they simply provide a language for us to talk about modality, and what could be more accommodating to the realm of literature than to conceive of a relation to the world-or worlds-in terms of a language, and a non-binding one at that?

Pavel and Doležel have themselves remarked that the language thus offered by philosophy runs into a fundamental problem - which will be revisited below - when it attempts to account for internally contradictory fictions, and can thus not serve as a ready-made solution for the purposes of narrative theory. What is most striking, however, is that one proponent of possible worlds theory-who gets a very short 
hearing by a number of those that would aspire to offer a theory of fictional worlds denies altogether that possible worlds are, in so many words, elements of a language, however technical that language may be. The philosopher in question is David K. Lewis, (in)famous for his vigorous challenge of the widely-held belief just reported, according to which possible worlds are abstract rather than concrete entities, and thus could not be said to exist in the same way that 'our' world exists. Lewis instead espouses what he terms modal realism, proposing that we include in our ontology not just all of that which is actual, but also, and in addition, everything that is possible. (In effect, 'actual' is here to be understood deictically as pointing to one among many possibilities, the one with which we are presumably familiar.) Equal rights of existence are thus granted to that which is actual and to that which is 'only' possible, that is: to possible worlds in which, counterfactually, states of affairs obtain that differ from the actualized ones. Realism about possible worlds asserts that the worlds in question are not mere abstract stipulations but exist in the modal universe as incontrovertibly as anything we might reach out and touch, even though—naturally—neither looking nor touching are an option in the case of possibilia.

This theory deserves the moniker 'realism' because, put in the most basic terms, it insists on a reality beyond language. Modal realism proposes the view that possible worlds are part and parcel of our ontological furniture; they are no less real and concrete than the actual world before us, and like the latter they are- to the realistindependent of any language used to refer to them. In his book On the Plurality of Worlds," Lewis from the outset rejects the idea that language could have a world-making hand in the creation of possibilia: "The worlds are not of our own making. ... We make languages and concepts and descriptions and imaginary representations that apply to worlds (On the Plurality of Worlds 3). ${ }^{\vee}$ If possible worlds are not made by us, but languages and any means of representation in general are, this implies, as Lewis will point out later in the book, that worlds have the potential to "outrun our means of describing them" (165). We may well aspire to make parts of worlds-since, obviously, languages are part of those worlds (be these actual or possible) in which they operate-but according to Lewis we do not make the worlds themselves as causally isolated wholes. We therefore cannot principally preclude elements of possible worlds that we might not 
be able to successfully address with the help of those parts of the same world called 'language,' 'concepts,' or 'representations.' The ontology of possible worlds is so pluralistic that, according to Lewis, "absolutely every way that a world could possibly be is a way that some world is" (2) -and some of these ways just may not be amenable to description.

The reason I dwell on this rather entertaining bit of metaphysical speculation is not to provide conclusive evidence against the death of God that has long since been announced, or against the diagnosis of a 'post-metaphysical age' delivered (though hardly with any Nietzschean undertones) by Jürgen Habermas. Rather, I focus on Lewis' particular brand of possible worlds theory because it finds itself intertwined in an intriguingly complex fashion not just with literary studies but with literary text itself. Lewis is not only among those possible worlds theorists who have explicitly written on the analysis of fictional discourse; his work is also the direct point of reference in a cycle of poems by the contemporary French poet Jacques Roubaud that will be the object of my reflections below. ${ }^{\text {vi }}$ Roubaud's poems mark the vertiginous ability of literary fiction read broadly (that is, not strictly confined to extended prose narrative) to re-inscribeor, as we might put it: to re-fictionalize- the very theory that would assign fiction a particular spot in its own philosophical architectonic. Literature thus enters into an exchange with possible worlds theory that is not predicated on a shared question to which alternative answers are provided (that sort of exchange tends to be confined to intradisciplinary contexts), but rather constitutes an altogether less predictable encounter.

To wit, it is Lewis, not someone like Kripke, who is invoked as a point of literary reference in Roubaud's poetry. Someone, that is, who flatly denies any role of poiesis in our relation to possible worlds, and, even though he avoids mention of the telescopes mocked by Kripke, does not rule out the possibility that fiction "might serve as the means for the discovery of modal truth" (Lewis, "Truth in Fiction" 278). Why would this type of realism that explicitly denies language and metaphor any world-making (or, in Kripke's terms, stipulative) powers be of interest to a poet? In what follows, I will attempt to develop an answer to this question. 
It is important to note that Lewis does not present his metaphysics of possible worlds as an absolute doctrine but rather as a way of doing philosophy with particular strategic advantages: "If we want the theoretical benefits that talk of possibilia brings," he writes, "the most straightforward way to gain honest title to them is to accept such talk as the literal truth" (On the Plurality of Worlds 4). The "literal truth" of the language of possible worlds would amount to saying that these worlds are not metaphorical realms in which we indulge at our leisure, or which are invoked in a dissimulative effort. For Lewis, there is something potentially dishonest about metaphor: its capacity to disguise would let us refer to an extraordinary number of new entities in order to solve a number of theoretical impasses without implying any clear commitment to the status of the entities thus invoked. In this particular respect, Lewis takes the call of his teacher Quine for ontological commitment (Quine 12) seriously, even though he radically rejects Quine's notion that such seriousness obliges one to be as ontologically parsimonious as possible. Lewis' interest in gaining "honest title" to the benefits of the theory he proposes means to follow them to their necessary conclusion even if that conclusion should seem strongly counterintuitive, which indeed it has to those on whose faces Lewis" theory has met with what he himself dubbed the "incredulous stare" (On the Plurality of Worlds I33-35).

While the intuitively scandalous 'cost' of an immense ontology of concrete possible worlds has been the primary bone of contention for the majority of Lewis' fellow analytic philosophers as well as for a number of narrative theorists, it is, arguably, the very prospect of such non-abstract plurality which makes Lewis' theory into a suitable poetic conduit for Roubaud. The theoretical benefits due him for his adventurous ontological commitment are, to be sure, of little import to the poet. He, too, calculates, but to different ends. Lewis, for his part, is led to assume that the theory he is proposing is true (while explicitly acknowledging that he is not aspiring to deliver conclusive proof) precisely because modal realism is "fruitful" (4); that is, it allows for systematically integrated answers to a whole range of interrelated philosophical problems such as the analysis of modality, causation, belief, and object properties. While the handy dispatching of long standing philosophical quandaries may be of no direct concern to the poet, modal realism will still bear fruit for his work. The process of 
grafting the former onto the latter, however, produces a decidedly different sort of yield.

In order to appreciate, rather than minimize, that difference, it behooves us first to consider in some more detail the theory of fiction developed by Lewis as part of the framework of modal realism. If the point of the latter is to establish and defend the literal truth of possible worlds talk, which role may any consideration of the non-literal play? The connection between both domains, so much is clear, is not one of simple equivalence for Lewis. In an extension of the aforementioned claim that worlds are not dependent on languages or other forms of representation, he insists that worlds are also nothing like stories or story-tellers (7). The reason that they are not is, once again, because possible worlds may well exceed that which stories, or their tellers, may be in a position to tell about them. Many fictions, so the argument goes, present only a tiny subset of the states of affairs that by logical implication may be considered to hold true in the worlds in which the fictions in question are set. At least as importantly, the nonnarrative nature of Lewis' worlds keeps them from the threat of internal contradictoriness. Stories, or storytellers, may contradict themselves, while contradictions cannot be true in any one given world considered as a whole. Thus, one crucial task of the array of indeterminately many possible worlds is to theoretically accommodate what would otherwise be strict contradictions in one and the same world.

The claim that worlds are not themselves stories or storytellers does not mean that stories or storytelling are completely outside the realm of interest of the modal realist; the literal-ness of the language of possible worlds by no means precludes fiction. Fictional discourse enters the picture not as the embodiment of a world, but as one way of referring to worlds. In his seminal article "Truth in Fiction," Lewis seeks to give an analysis of fictional discourse that would preserve a notion of truth governing its contents that remains consistent with the acknowledgement that, by definition, fiction is not committed to limiting its scope of reference to the actual world. Truth in fiction is here characterized as a restricted universal quantifier over possible worlds that allows closure under implication-which means, among other things, that fictional truth is not cut off from consequences it ought to imply under the law of non-contradiction. Leaving 
aside some of the more technical aspects of Lewis' analysis that are not of immediate concern here, the following applies for one of Lewis' main examples in this article, Conan Doyle's character Sherlock Holmes: the fictional claim that Holmes lived at 22 IB Baker Street - not true in the actual world, in which reportedly a bank building once stood at that London address - is true in any possible world where it is told as known fact that Holmes lived at that address, where it is true that he did live there, and which on the whole differs less from the collective belief world (the problematic assessment of which I will here factor out) than any world in which Holmes did not live at that address.

What is of particular interest about this analysis is the fundamental thrust of Lewis' view of fiction in its relationship to 'our world,' as he frequently calls the one possible world - actualized as it is - that surrounds us. The preservation of the kind of non-contradictoriness that Lewis cites in his rejection of the view of worlds themselves as stories or storytellers emerges as a key motivation here. In contradistinction to worlds, stories - or fiction, or literature tout court-can be contradictory. Over the course of the Sherlock Holmes stories, for example, as Lewis points out, Doyle located Watson's old war wound in different places, thereby creating internal contradictions that may be smoothed out via an analysis in terms of possible worlds that confines an inconsistency of this kind to a very small part of the worlds that contain Watson, presumably preventing "that just anything is true in the Holmes stories" (Lewis, "Truth in Fiction" 275).

Lewis' eccentrically rich ontology thus seems designed to establish a sense of logical neighborliness between our world and worlds portrayed in literature. Readers, he suggests in strictly hermeneutic spirit, look to "the least disruptive way of making [a given] supposition true" (269), and they are engaged in a "cooperative game of makebelieve" in which information from several sources is combined, in the basic manner of historiography, to establish consistency regarding any states of affairs in the background of a given piece of literature that are not detailed explicitly in the story (276). What readers end up with in this benevolent scenario is not merely one world in which a particular fiction takes place and on the features of which we must necessarily agree, but instead a certain array of relevant possible worlds not too far removed from each other 
with respect to their ontological layout. We are relieved_or so Lewis contends-from having to contemplate one world in which 22IB Baker Street was both a bank and the residence of a famous detective, or in which Watson's single wound is found in his left leg and his right arm simultaneously. Instead, we are invited to contemplate several worlds where either of these things are true but not both, some of which will differ in no other ways from each other, and in limited ways from our own. ${ }^{\text {vii }}$ These worlds will be-and this is crucial for our present considerations-radically separate from each other, no matter how closely their make-up resembles other nearby worlds. They remain absolutely inaccessible to each other, and even though they all exist-given that Lewis adamantly rejects the Meinongian notion of non-existent objects-they exist strictly in each other's absence.

One literary form which by its very definition deals with such absence is the lyrical genre of the elegy. Two poetry volumes by Jacques Roubaud, Quelque chose noir (translated into English as Some Thing Black) (1986) and La pluralité des mondes de Lewis (translated as The Plurality of Worlds of Lewis) (1991), may be said to belong to this genre. ${ }^{\text {viii }}$ The first of these two books constituted Roubaud's return to poetry after a period of silence of several years following the death of his second wife, Alix Cléo Roubaud, from pulmonary embolism at the age of 31 in 1983. While this biographical point of reference is palpable throughout these two cycles of poems, it introduces itself subtly because it is modulated by a strict attention to form, and is cast in a lyrical tone that is in many ways the exact opposite of the emphatic invocation that a reader familiar with earlier specimens of the genre might expect. Modern elegy, as Jahan Ramazani has emphasized, routinely presents "not so much solace as fractured speech, not so much answers as memorable puzzlings" (ix). Finding oneself confronted with what is puzzling leaves little space for the direct emotional charge of classical elegies, which prompts Ramazani to conclude that elegy in modernity tends to take on an anti-elegiac character. Whether or not we commit to regarding this as a strict reversal in generic terms, Roubaud, for his part, sees the confrontation of philosophical puzzles as part and parcel of the situation in which the mourning lyrical I finds itself. 
The adoption of Ludwig Wittgenstein as an implicit interlocutor in Quelque chose noir is directly related to the formal constraints derived from correspondences to the object of the elegies. Alix Cléo was not only an accomplished photographer but also-as we know from her diary that was posthumously edited by Roubaud—working on a study of Wittgenstein's theory of the image that never saw completion. I have described elsewhere how Roubaud, as he seeks a poetic language of mourning that incorporates elements of the one whose absence is being mourned, characterizes the search for such a language by distinguishing it from the Wittgensteinian theory of language games according to which even the specter of death-figured in the poem "Méditation de la certitude" as a contemplation of the hand of the corpse-might be subject to doubt and reinterpretation. ${ }^{i x}$ The lyrical I insists here that

aucun jeu de langage ne pouvait déplacer cette certitude. ta main pendait au bord du lit.

(“Méditation de la certitude," Quelque chose noir 13)

no language game could budge this certainty. your hand hung down from the bed.

("Mediation on Certitude," Some Thing Black II)

Yet, inscribing the visual perception into the poem by putting it into a relation of resemblance to Wittgenstein's invocation of G.E. Moore's emphatically raised hand(s) ${ }^{x}$ begins to unsettle the alleged certitude claimed against a view of language known for its responsiveness to the context of any utterance.

The third section of Quelque chose noir includes not only a direct reference to Wittgenstein's name in the title of a poem (45) but also calls up a philosophical point of view that finds itself at some remove from Wittgenstein's perspective on a world as a singular entity of which both the work of art and thought, as he at one time speculated, might offer "the right perspective."xi In the consecutive poems "Roman-photo" and 
"Roman, II," the lyrical I thus shifts to the perspective of (a) hypothetical novel(s) presenting possible worlds in which the lyrical I ("Il y a quelqu'un, un homme. II n'est pas nommé.") and the mourned other ("Il a sa jeune femme, qui est morte.") find themselves in different circumstances, including worlds where her deathcounterfactually — has not taken place. The representation of these possibilities is articulated not just in the language of fiction — given that the lyrical I of any poem is never simply a truth-telling extension of the author-but in the fiction of fiction. The lyrical I in the poem contemplates the possibility of a novel in which the life of an unnamed man plays out within a modal realm different both from that of the enveloping lyrical frame and, likewise, of the frame that comprises the lyrical l's author, one "Jacques Roubaud." The following poem, "Roman, II," pushes the incompatibility between these realms to the point of imagining a novel ("un autre roman encore, peutêtre le même") in which the man receives a phone call from his dead wife. What would this man do in that case?

Il décrochera, et il entendra sa voix. Le monde où il est encore (le téléphone vient de sonner mais il n’a pas encore bougé la main pour répondre) sera oublié.

(“Roman, II," Quelque chose noir 53)

He will pick up the receiver and hear her voice. This world where he still is (the phone has rung, but he has not yet moved his hand in order to answer) will be forgotten.

(“Novel, II,” Some Thing Black 5I)

In fact, as the further elaboration of the situation in the poem shows, the world of the lyrical I in which the possible world of his wife's non-death is imagined necessarily ceases to be possible itself if the state of affairs in the imagined world is taken as the measure of actuality-a world in which the lyrical I has battled for thirty months with the impact 
of the death in question, and in which death arguably remains the limit-concept of experience for any human being. Given this confrontation of two incommensurable worlds, the telephone here cannot serve its anticipated function as a communicative medium. There is nothing to say to an inhabitant of a world in which that which is at the root of the radical separation between the two speakers simply does not apply.ii The struggle with death is translated into a language of fiction that is at war with itself: enunciating a possibility which, upon reflection, reveals itself as an impossibility, it battles against the very silence that the early Wittgenstein had suggested be employed outside the border delimiting both world and language.

This linguistic struggle against silence continues in La pluralité des mondes de Lewis, with conceptual references to Wittgenstein largely replaced by those to Lewis' modal realism in the first part of the book, a cycle of 30 numbered poems written between 1987 and 1990 that bears the same title as the book itself. In a continuation of the elegiac invocation of the dead other, these poems expand the consideration of possible worlds begun in Quelque chose noir to universes shaped explicitly by Lewisian terminology. The indexicality of the 'actual' world as analyzed by Lewis makes the absence of the other person in the world of the poetic voice felt all the more acutely, while that person is simultaneously pictured—and directly addressed as 'you' (tu/toi)—in possible worlds that contain her alive, either with (as in poem [vii]) or without (as in poems [vi] and [xxv]) the lyrical I himself present. The addressing of 'you' here emerges as an affirmation of possibility within the parameters of Lewis' metaphysics; everything that can be said is hence to be considered possible in some world, while impossibility is reserved for all that does not apply in any world:

l'impossible, en aucun monde, n'est le cas.

et dans un monde tout, toujours, n'est que possibles.

aucun impossible ne peut être dit

autrement, ailleurs 
qu'en disant. je ne tais rien

disant : 'toi'.

je ne montre rien non plus.

([xx], "Voie de l'impossible," La

pluralité des mondes de Lewis 29)

the impossible is not the case in any world.

in any world all things, always, can only be possibilia.

nothing impossible can be said

otherwise, elsewhere

except by saying. I hold nothing back

by saying: "you."

and I show nothing either

([xx], "The Way of the Impossible," The

Plurality of Worlds of Lewis 30 )

In a loosening of the restriction that the early Wittgenstein of the Tractatus had placed on the contents of a singular world as equivalent to "all that is the case," the plurality of worlds envisioned by Lewis does allow for speaking of that which is not actually the case. It allows for speaking of the possible of which the actual—as actualized possibility-is 
but a part. But what sort of modal status should be reserved for the 'you' that is here not held back as strictly unsayable? $?^{\text {xiii }}$ While the very enunciation of the personal pronoun-in an avoidance of the proper name, ${ }^{\text {iv }}$ but likewise of radical silenceappears to indicate the possible presence of the one whom the word deictically denotes, the elegiac context in fact implies the very opposite; the radical discontinuity between the world of the mourner and the possible world of the mourned as alive (and hence as not-to-be-mourned) condemns the notion of address and communication to impossibility. And yet, as the third sentence of the quoted passage asserts with unavoidable ambiguity, there is no articulation of the impossible that does not automatically entail the creation (or, as Lewis would prefer, the identification) of possibilia. The emergence of such possibilia, however, does not amount to the showing of anything, as Wittgenstein had claimed the mystical (das Mystische) does, stepping up where language fails. ${ }^{x v}$ As in the ekphrastic outline of the hypothetical "Photo-Novel" in the poem of the same name, there is nothing to see here, yet simply moving along is not an option. Still, tarrying (taire) in hopes of an eventual appearance of the subject addressed is ultimately an exercise in futility, no matter how long the wait, or the way. Lewis himself terms the vision of the modal realist an ontological "paradise" (On the Plurality of Worlds 4), a land of metaphysical plenty that he defends against those who would take up Occam's razor to shave it down to a more parsimonious size, and which he insists cannot be had "on the cheap" by thinking of possible worlds as mere abstract representations that do not require ontological commitments. The provocation that Roubaud's poetry discovers at the dark heart of this paradise-and the reason why the latter serves as an apt background for the meditations contained in these poems-is that the promise of possibility goes hand in hand with radically isolating each world and precluding access to it from any other realm. ${ }^{\text {xvi }}$ As Lewis writes, "trans-world individuals are ... impossible individuals" (On the Plurality of Worlds $2 \mathrm{II}$ ), which means that according to Lewis individuals do not retain strict identity (sometimes called this-ness, or quiddity) across possible worlds. This sort of identity would enable them to engage in transworld travel - the migration between worlds without relinquishing their identity-to access other possibilia while strictly remaining themselves. Lewis instead argues, in oftentimes very technical terms, for a counterpart theory according to which individuals 
across possible worlds - for example, Roubaud's lyrical I in the present situation in which his wife has died, and that lyrical I in a possible world in which she is still aliveare not bound by a strict relation of identity but rather by a counterpart relation which lets one represent the other. Lewis explains this sort of relation with reference to a possible world in which Hubert Humphrey wins the presidential election (which he in fact lost) against Nixon in 1968:

Humphrey may be represented in absentia in other worlds [including those in which he wins the 1968 election], just as he may be in museums in this world. The museum can have a waxwork figure to represent Humphrey, or better yet an animated simulacrum. Another world can do better still: it can have as part a Humphrey of its own, a flesh-and-blood counterpart of our Humphrey, a man very like Humphrey in his origins, in his intrinsic character, or in his historical role. By having such a part, a world represents de re, concerning Humphrey - that is, the Humphrey of our world, whom we as his worldmates may simply call Humphrey - that he exists and does thus-and-so. (Lewis, On the Plurality of Worlds 194)

The corrosive implications of such representation in absentia across possible worldswhether these representations be of a political representative or a deceased belovedare not hard to fathom. The possible existence that is held out like the Cartesian promise of a durably shaped piece of wax or an automaton of stunning likeness, is, in the end, a representation of an absence as much as a representation in absence. The radical difference in register that such an absence carries in the humorous example of the wax museum invoked by Lewis, and the deeply personal character of a tragic loss as it is figured in Roubaud's poetry, respectively, constitutes a considerable challenge to our reading habits in both directions. Roubaud's unconventional type of elegy forces the attentive reader to contemplate the referential backdrop of a philosophical discourse that is nowhere explicitly concerned with the possible existential weight of being incontrovertibly separated from one's own counterpart or from that of a beloved dead other. Lewis' system of metaphysics, on the other hand, while it owes its conception to strictly logical considerations, cannot fully shield itself from a reading that would ask 
how one of its conceptual centerpieces such as the 'counterpart' might fare in a world that allowed it to be inscribed into a literary rendering of the harrowing experience of mourning. Roubaud takes up the latter scenario in the following lines:

on ne passe pas d'un sous-monde à l'autre. on ne passe pas vivant. ni mort.

$[\ldots]$

(tu y mourras, moi ici)

en contrepartie tu es, tu es, là, encore. C'est la seule consolation. je ne la nommerai pas survie.

([xxv], “Partage de monde," La pluralité des mondes de Lewis 34)

one cannot cross from one sub-world to another, one cannot cross alive. or dead.

\section{$[\ldots]$}

(you will die there, I here)

as a counterpart you are, are there, still. It is the only consolation. I would not call it survival.

([xxv], "Division of World,"”vvii The Plurality of Worlds of Lewis 35)

Comparable to the ambiguous existence as a paradoxical pronoun used in an address, being as counterpart is not nothing; it is a mode of being held out "in return" (en 
contrepartie) for the realization of death, the minimal (and maximally available) consolation given the necessary causal separation of worlds. ${ }^{\text {xviii }}$

Such minimal consolation, however, should not be confused with achieved redemption. Poetic language that points to absence in this way closes itself off from bridging with any sort of permanence the gap between what may or might be named (nommerai) and that which is being named. The radical affirmation of contradictorinessin the manner of someone like Nietzsche who praised the writer (and famously unsuccessful suicide) Chamfort as someone "who found laughter necessary as a cure against life, and who nearly considered himself lost every single day he passed without laughing"xix —is barred in the metaphysical design of Lewis' worlds, but it surges up again in Roubaud's elegiac poems at the very moment that these appear to adopt this philosophical perspective for consolatory purposes. With internal contradictions in each world 'successfully' prevented, the notion of a communicable paradox of simultaneous life and death within the same sphere cannot be cogently entertained. It can only be asserted in a conditional that strictly contradicts Lewis' own tenets as we explored them above:

si les mondes étaient des contes, leurs habitants des conteurs,

et pas seulement leurs êtres mais tout, toutes choses, toutes

racontant leurs histoires, racontées

il y aurait place pour des mondes

où des contradictoires seraient vrais

où je dirais "tu vis, tu es morte"

riant, tu répondrais 
([xix], “La Voie du Conte,” La pluralité des

mondes de Lewis 28)

if worlds were stories, their inhabitants storytellers,

not just the living beings, but all, all things, all

telling their stories, all being told

there would be room for worlds

where contradictions could be true

where I could say "you live, you're dead"

and with a laugh, you would reply

([xix], "The Way of Stories," The Plurality of

Worlds of Lewis 29)

Laughter in response to the contradictoriness of a world itself, fit to be invoked only in an impossible hypothetical, is not available in worlds governed by Lewis' determination that they are not stories, only possible referents of the latter. The paradise of noncontradictory possible worlds sketched out in philosophical discourse leaves it to poetry to articulate the impossible, that which is cast out and without title, that which does not fit the schema.

This remainder even manifests itself, in all of its offensive contradictoriness, as printed externally on the page. The sixth of the 30 poems in the cycle was translated into English by Roubaud—a self-professed anglophile—himself; the French and English 
versions are printed on facing pages in the original French edition, beginning with the following lines:

Clean world, clean world, not deceptive, but absent

if it is absent, it is nowhere, you are nowhere, and that's that.

([vi], La pluralité des mondes de Lewis I4;

The Plurality of Worlds of Lewis 16)

monde propre, propre, qui ne trompe pas, qui ne s'absente, et si absent, alors de nulle part; tu es nulle part, voilà tout.

([vi a], La pluralité des mondes de Lewis I5)

In an inverted echo of the "dirtiness" of the world of the lyrical I of Quelque chose noir in which life and death find themselves intermingled ("'Sale vie, sale vie mélangée à la mort" ["Méditation de la pluralité"; Quelque chose noir 80]), the cleanliness of the Lewisian metaphysical layout initially appears to provide welcome relief through the creation of well-ordered states of affairs, cleansed of the dirty bastardization of what does not belong to the same order. The disjunction, however, between the triple meaning of the French "propre" (signifying not only 'clean' but also 'honest and 'own') and the streamlined English translation linguistically exposes the full existential contradictoriness of the situation: the possible world in which the dead other exists as living being is "clean" in that it does away with conceptual messiness, and it is "honest" (it does not philosophically deceive, giving its proponent "honest title" to it, as Lewis remarked), since its radical inaccessibility is fully acknowledged. Meanwhile, however, the "own world" (monde propre) of the lyrical I does not "absent itself" (in contrast to the "clean world" which the English text postulates as present rather than absent)-it persists at the very same time that possibilia are being entertained, making them into impossibilia, as the scenario of "Roman-Photo" also demonstrated. Thus, what at first glance looks like a more or less unproblematic carrying over of meaning from one 
linguistic realm to another in fact opens up the ineradicable gulf of difference persisting between languages, and between the worlds to which these languages - given that they are not worlds - would refer. It is a demonstration of incommensurability in the guise of a translation, one which the English version of the book, The Plurality of Worlds of Lewis, could only have matched by reprinting poem (vi a) in the original French. ${ }^{\mathrm{xx}}$ Roubaud's reader is confronted with two distinct poetic perspectives on possible worlds that each exist for themselves with the full positive force that this verb implies, but which, on the other hand, remain absent to each other, separated as they are on facing pages of the same book.

The vexing way in which the question of translation bears on the question of (the impossibility of) transworld travel, counterpart relations, and communication indicates that the elegiac context of Roubaud's poem cycles, while on the one hand very directly tied to the specificities of a personal life, ultimately reaches far beyond personal mourning in its implications. With this extension of perspective in mind, we may return once more to Lewis' confrontation of the particular challenges that fiction poses for his metaphysical account. In the last of four postscripts to the reprint of "Truth in Fiction," Lewis cites a fictional ballad, sung by a boastful singer portraying himself as the stockman Ugly Dave, capable of any number of amazing exploits and culminating in the hyperbole “In fact, l'm duke of every blasted thing” (Lewis, “Truth in Fiction” 279). The philosophical problem in dealing with a fictional song such as this, Lewis notes, is how to give an account of a singer pretending to be Ugly Dave, who in turn pretends to tell the truth about himself as an amazingly powerful stockman. How to distinguish, in other words, "pretending to pretend from really pretending" (280)? Although Lewis does not say so explicitly, this problem is far from merely presenting a tricky special case, and in fact goes to the very core of fictional discourse. As countless examples of complex fictional structures demonstrate, the "pretense"- that is: the invocation of a non-actual state of affairs - cannot necessarily be strictly isolated to one layer where it may be clearly distinguished from a discernible 'reality' of the instance engaging in the pretending. This is so because, in short, there can be impossible fictions. ${ }^{x \times i}$

Roubaud's lyrical I may poetically invoke-or: 'pretend the existence of -a possible world in the poem "Roman, Il" (in Quelque chose noir) in which the dead other 
dials his number. He may likewise invoke a novel which narrates this situation, a state of affairs that is strictly impossible by Lewisian lights, and one which the lyrical I himself, as he acknowledges, "will not, in fact, truly be capable of imagining himself" (Quelque chose noir 54). How do we distinguish between the lyrical I pretending to pretend that the telephone might ring, and his pretending that it really might ring? How do we distinguish, that is, the lyrical I pretending to write (or star in) a novel pretending to narrate an impossible situation from him pretending to experience an impossible situation?

To the extent that we recognize elegy to be an example of a fictional genre which by design runs up against the boundaries of pretense - the fictions to which we tend to resort in order not to contemplate death-we might not feel compelled to insist on any distinction at all. That is not to say that the drawing of a distinction makes no difference. Quite to the contrary, without its lyrical invocation of a "Photo-Novel" that does not, in the end, show anything, this poem would become a radically different text. It would not thereby, however, necessarily differ in its measurable proximity to an assumed world which was radically "honest" to the point of being devoid of any fiction or metaphor whatsoever.

One noteworthy response to the Ugly Dave conundrum, given by Jim McKenzie in the context of a volume expressly dedicated to the memory of David Lewis in 2004, three years after Lewis' death, amounts to a deflationary solution of the problem at hand in terms of genre:

The genre into which this interpretation places the singer's performance, the extravagant yarn, is common to many lands. ... Only a listener with no appreciation of the point of the narrative could suppose that Ugly Dave was sincerely describing himself as a great stockman.... What Lewis fears, the collapse of the iteration, is prevented by the audience's literary taste. Those who listen to ballads about stockmen need not have a highly cultivated appreciation of literary forms and genres, but there are some mistakes even they can avoid. (McKenzie 139)

While the aesthetics of reception might well ensure the unproblematic enjoyment of Lewis's fictional yarn among folk song aficionados (Lewis himself-no enemy of fictions, 
popular or otherwise - was known to have great affection for the lore of the Australian bushlands), it seems less clear whether any undisputed genre features would without fail disambiguate the reinscription of modal realism into the genre of the contemporary elegy. Or, likewise, whether an encomium such as McKenzie's own would not, in the end, have to be measured according to elegiac criteria as much as philosophical ones when it culminates in a conflation of Ugly Dave with the philosopher who brought him into existence, one bearing the same first name:

Ugly Dave's greatness lay not with an axe or a stockwhip, but with words and with his mind. He was a great storyteller and user of language. He could string together ideas in elaborate connections, in ways nobody else could have expected, enabling us to visualize things we had never dreamt of, and to think thoughts we had never thought before. He led us to understand what we could not otherwise even have conceived, as if he had a direct line to other and more fantastic worlds. (ibid.)

The genre of "Ugly Dave's" writings is here tilted from metaphysical analysis in the declarative mode over the edge that presumably separates truth-telling from pretense into the realm of storytelling. Even as he insisted that worlds are not stories, McKenzie implies, Lewis told stories about worlds. He helped visualize that which would not simply show itself of its own accord. He promoted an understanding of what, absent such storytelling, would have remained inconceivable. And he was able to do so, writes McKenzie in his own poetry of praise and lamentation, because it seemed as if Lewis had the very sort of communicative connection to another possible world that Roubaud contemplates in "Roman, II" in all its theoretical inconsistency-a telephone line which, if actually used, would have to transmit speech one could not possibly understand. If worlds were stories, Lewis could indeed have told them. But they are not. To the extent that it seeks to avoid becoming poetry, modal realism must reject this counterfactual. 
See Doležel, Heterocosmica 23 I n24. A good sense of the spread of disciplines involved in the discussion of possible worlds may be gained by perusing the volume Possible Worlds in Humanities, Arts and Sciences edited by Allén.

ii See Pavel 49; Doležel, "Possible Worlds and Literary Fictions” 235. Even more skeptical concerning a straight transfer of the notion for the purposes of fictional theory is Schaeffer (207).

iii Pavel does avail himself of Lewis' counterfactual analyses but rejects the metaphysical stance of modal realism as "an extreme position, which offends our most common intuitions" (Pavel 49) —an assessment which Lewis himself does not contest (Lewis, On the Plurality of Worlds 133). Despite the remarkable range of Doležel's Heterocosmica in its consideration of the relevance of possible worlds for narrative theory, the book declines to offer any perspective on modal realism, which may be why its author can flatly maintain at the outset that "[c]ontemporary thinking about possible worlds is not metaphysical” (Doležel, Heterocosmica 14). Marie-Laure Ryan, even though she takes Lewis' position to imply a "counterintuitive view of actuality" that deprives the latter of its "uniqueness" (Ryan 18), nevertheless recognizes more value than most in modal realism for an analysis of fictional universes (23); it is not clear, however, to what extent the unambiguous ontological stand-off between Lewis and someone like Rescher, which she acknowledges, is resolved in her own account.

iv Bricker provides a helpful, non-technical summary of the main philosophical theses of Lewis' book.

v Even though Lewis nowhere explicitly refers to Nelson Goodman's later work, a negative echo of Goodman's well-known book title, Ways of Worldmaking (1978), may be discerned here. Whereas Goodman seeks to develop a wide concept of reference that would surrender the so-called actual world for the benefit of all manner of signdependent worlds (or 'world versions') such as those conceived in visual art, music, fiction, and science, Lewis is strictly opposed to any notion that would give semiotics a hand in creating worlds.

vi Another piece of contemporary literature that picks up on Lewis' theory is the play Possible Worlds by the Canadian mathematician and playwright John Mighton (1992); see Klaver.

vii In his second Postscript to the text of the original article, Lewis proposes a socalled "method of union" of maximally consistent fragments to deal with cases of internally inconsistent fictions; by relegating incompatible elements to separate "strands" of one fiction, an overall inconsistency of a given piece of fiction would be avoided, albeit at the considerable price of fragmenting a whole which once again stands to be united in logical terms. Richard Hanley expands and defends this line of argument, but his objections to the very notion of self-embedded fictions - which he rightly diagnoses as problematic both for Lewis and for his own defense of this view (Hanley 126)-seem far from conclusive. 
While the protracted scholarly debate surrounding the status of elegy as a genre is not of immediate relevance for the present context, it is worth noting Morton Bloomfield's helpful characterization of elegy as a genre and the elegiac mode, respectively, as nested sets; he considers all elegies more narrowly defined to partake of the elegiac mode as a "mode of approaching reality" (Bloomfield I48), but not all poems in the latter mode to be elegies in the classical sense. The metrical form of Roubaud's elegies is by no means classical, but their numerological constraints (see Montémont 333-4) and form of personal address clearly tie them to the classical elegy tradition characterized by Bloomfield as "expressing both love and lamentation" (Bloomfield I4950). For sake of clarity I have slightly modified the existing translations of passages from Roubaud's poems in the following; the page numbers of the published translations are provided for ease of reference.

ix See Klebes |58-6|.

x See Wittgenstein, On Certainty.

xi Wittgenstein, Culture and Value 6-7. In his reading of Wittgenstein's example of the Paris Urmeter (see Philosophical Investigations, §50), John Gibson succinctly explains in what way this sort of "right" perspective conflicts with the view that a philosophical realist such as Lewis might defend: "The point [for Wittgenstein] is, we are able to represent and refer to the world in speech because we use the world as a standard of representation and reference when speaking about the sundry objects we experience. And so when we want to illuminate the nature of the objects we talk about - what we are saying about the way the world is when we say that this is that sort of thing - we do not try to take a stab at the nature of the thing as it 'really' is apart from how we say it is. We come to our understanding of the reality of the things we talk about by reflecting on the story of how these bits of the world have been brought into and given shape by our way of life" (Gibson 57).

xii Wittgenstein offers the poignant counterfactual: "If a lion could talk, we could not understand him" (Philosophical Investigations 223); it is in this sense that Roubaud's fictonal scenario testifies to the impossibility of communication and understanding between inhabitants of incommensurable possible worlds.

xiii The ontological weight of this question may be measured against Quine's thesis that "to be is to be within the range of reference of a pronoun" (Quine 13).

xiv On the metonymic substitutions of the name 'Alix Cléo' in Quelque chose noir, see Poucel 193.

xv See L. Wittgenstein, Tractatus logico-philosophicus, prop. 6.522.

xvi Another affinity between the literary work of the mathematician Roubaud and the metaphysics of the modal logician Lewis, which I will not explore here, is the central importance of set theory as a systematic template for both; regarding Roubaud's ties to the set-theoretical Bourbaki project see Klebes 146-8. 
xvii Rosmarie Waldrop translates "Division of Worlds," but use of the singular seems appropriate here since the 'sub-worlds' are pictured as emerging from a larger whole.

xviii In his study on mourning and elegy, William Watkin concisely notes that "death's gap," the radical absence denoted by elegy, "puts causality to death" (62). This fittingly explains why the causal isolation of Lewis' possible worlds provides a compelling template for Roubaud's elegies, but also why the notion of a seamless transfer of causal inference as it is employed in the actual world into fiction may present philosophical problems.

xix Nietzsche 126 ( $\$ 95 ;$ my translation).

xx In the translated volume, poem (vi a) is omitted altogether while (vi) is reprinted as is from La pluralité des mondes de Lewis. The differences between the two poems can therefore be gleaned only from the original text.

xxi Doležel acknowledges these as limits to his narratological possible worlds project: "We have no satisfactory metalanguage for describing the semantic status of narrative worlds lacking authenticity: our thinking and our language are dominated by binary oppositions. Literary narratives proposing worlds without authenticity reveal the limitations of this binarism; they use and abuse the world-constructing force to question the universality and validity of our metalinguistic dichotomies. Self-voiding narratives simulate narrative texture but cannot bestow fictional existence, cannot affirm fictional facts. They subvert the very foundations of fiction making and create constructs suspended between fictional existence and nonexistence" (Doležel, Heterocosmica 163).

\section{Works Cited}

Allén, Sture, ed. Possible Worlds in Humanities, Arts and Sciences. Proceedings of Nobel Symposium 65, held on August II-15, 1986, at the IBM Nordic Education Center, Lidingö, Sweden. New York and Berlin: de Gruyter, 1989.

Bloomfield, Morton W. "The Elegy and the Elegiac Mode: Praise and Alienation."

Renaissance Genres: Essays on Theory, History, and Interpretation. Ed. Barbara Kiefer

Lewalski. London and Cambridge, Mass.: Harvard University Press, 1986. 147-57.

Bricker, Phillip. "David Lewis: On the Plurality of Worlds.” Central Works of Philosophy:

The Twentieth Century: Quine and After. Ed. John Shand. Montreal: McGill-Queen's University Press, 2006. 246-67. 
Carnap, Rudolf. “The Elimination of Metaphysics through Logical Analysis of Language.” Trans. Arthur Pap. Logical Positivism. Ed. A.J. Ayer. New York: Free Press, 1959. $60-81$.

Doležel, Lubomír. Heterocosmica: Fiction and Possible Worlds. Baltimore and London: Johns Hopkins University Press, 1998.

---. "Possible Worlds and Literary Fictions." Possible Worlds in Humanities, Arts and

Sciences. Ed. Sture Allén. New York and Berlin: de Gruyter, 1989. 221 -42.

Gibson, John. "Reality and the Language of Fiction," in Writing the Austrian Traditions:

Relations between Philosophy and Literature. Ed. Wolfgang Huemer and Marc-Oliver

Schuster. Edmonton: Wirth-Institute for Austrian and Central European Studies, 2003. 49-65.

Goodman, Nelson. Ways of Worldmaking. Indianapolis: Hackett, 1978.

Hanley, Richard. “As Good As It Gets: Lewis on Truth in Fiction.” Lewisian Themes: The Philosophy of David K. Lewis. Ed. Frank Jackson and Graham Priest. Oxford: Clarendon, 2004. I I3-129.

Klaver, Elizabeth. "Possible Worlds, Mathematics, and John Mighton's Possible Worlds.” Narrative I4.I (January 2006): 45-63.

Klebes, Martin. Wittgenstein's Novels. London and New York: Routledge, 2006.

Kripke, Saul. Naming and Necessity. $2^{\text {nd }}$ rev. and enl. ed. Oxford: Blackwell, 1980.

Lewis, David. "Truth in Fiction.” Rpt. in Philosophical Papers. Vol. I. New York and

Oxford: Oxford University Press, 1983. 26I-80.

---. On the Plurality of Worlds. Oxford: Blackwell, 1986.

McKenzie, Jim. "The Ballad of Ugly Dave.” Lewisian Themes: The Philosophy of David K.

Lewis. Ed. Frank Jackson and Graham Priest. Oxford: Clarendon, 2004. I 38-I39.

Montémont, Véronique. Jacques Roubaud: L'amour du nombre. Lille: Septentrion, 2004.

Nietzsche, Friedrich. Die fröhliche Wissenschaft. Kritische Gesamtausgabe. Part V. Vol. 2.

Ed. Giorgio Colli and Mazzino Montinari. Berlin and New York: de Gruyter, 1973.

Pavel, Thomas. Fictional Worlds. Cambridge, Mass.: Harvard University Press, 1986.

Poucel, Jacques. Jacques Roubaud and the Invention of Memory. Chapel Hill: University of North Carolina Department of Romance Languages, 2006. 
Quine, W.V.O. “On What There Is.” Rpt. in From a Logical Point of View. $2^{\text {nd }}$ rev. ed. Cambridge, Mass.: Harvard University Press, 196I. I-19.

Ramazani, Jahan. Poetry of Mourning: The Modern Elegy from Hardy to Heaney. Chicago: University of Chicago Press, 1994.

Roubaud, Jacques. La pluralité des mondes de Lewis. Paris: Gallimard, 199I.

---. The Plurality of Worlds of Lewis. Trans. Rosmarie Waldrop. Normal, III.: Dalkey Archive, 1995.

---. Quelque chose noir. Paris: Gallimard, 1986.

---. Some Thing Black. Trans. Rosmarie Waldrop. Elmwood Park, Ill.: Dalkey Archive, 1990.

Ryan, Marie-Laure. Possible Worlds, Artificial Intelligence, and Narrative Theory. Bloomington and Indianapolis: Indiana University Press, 1991.

Schaeffer, Jean-Marie. Pourquoi la fiction? Paris: Seuil, 1999.

Watkin, William. On Mourning: Theories of Loss in Modern Literature. Edinburgh: Edinburgh University Press, 2004.

Wittgenstein, Ludwig. Culture and Value. Rev. Ed. Georg Henrik von Wright with Heikki Nyman. Rev. Ed. Alois Pichler. Trans. Peter Winch. London and New York: Routledge, 1998.

---. On Certainty. Corr. Repr. Ed. G. E. M. Anscombe and G. H. von Wright. Trans. Danis Paul and G. E. M. Anscombe. Oxford: Blackwell, 1974.

---. Philosophical Investigations. $2^{\text {nd }}$ Ed. Trans. G. E. M. Anscombe. Oxford: Blackwell, 1958.

---. Tractatus logico-philosophicus. Trans. D.F. Pears and B.F. McGuinness. London and New York: Routledge, 1974. 